\title{
Effect of the Inulin Addition on the Properties of Gluten Free Pasta
}

\author{
Marcella Mastromatteo ${ }^{1}$, Mariapia Iannetti ${ }^{1}$, Valentina Civica ${ }^{1}$, Grazia Sepielli ${ }^{2}$, \\ Matteo Alessandro Del Nobile ${ }^{1,2}$ \\ ${ }^{1}$ Istituto per la Ricerca e le Applicazioni Biotecnologiche per la Sicurezza e la Valorizzazione dei Prodotti Tipici e di Qualità, \\ University of Foggia, Foggia, Italy; ${ }^{2}$ Department of Food Science, University of Foggia, Foggia, Italy. \\ Email: ma.delnobile@unifg.it
}

Received April 29 $9^{\text {th }}, 2011$; revised September $1^{\text {st }}, 2011$; accepted September $8^{\text {th }}, 2011$

\begin{abstract}
In this work the influence of the soluble fiber content, such as inulin, on both the sensory quality of dry spaghetti based on maize and on the dough rheological properties were evaluated. The inulin was added to the dough up to an amount of $20 \%$. Results showed that the samples with inulin at $5 \%$ and $7.5 \%$ showed the higher values of elongation and shear viscosity with respect to the other samples, therefore a higher firmness. Regarding the sensorial analysis, all dry samples had a positive score of overall quality; in particular, the sample with $5 \%$ of inulin showed the highest score because of the highest resistance to break value. Moreover, the overall quality of the cooked spaghetti samples decreased with the increase of the amount of inulin. In fact, firmness, color and taste attributes decreased with the increase of the inulin amount influencing negatively the overall quality of the spaghetti samples.
\end{abstract}

Keywords: Gluten Free Pasta; Rheological Characteristics; Sensorial Properties

\section{Introduction}

Pasta product, largely consumed all over the world is traditionally manufactured from durum wheat semolina, known to be the best raw material suitable for pasta production [1]. However grains different from durum wheat have been used (as partial or total substitutes) in production of particular kinds of "pasta" with healthy characteristics or directed to specific targets, such as people following a celiac diet [2]. The reaction to gluten ingestion by sufferers of celiac disease is inflammation of the small intestine leading to the poor absorption of several important nutrients including iron, folic acid, calcium and fat soluble vitamins [3]. A strict gluten-free diet is currently the only treatment for celiac disease and requires the complete removal of all wheat, rye and barley products. On the other hand, diets that contain moderate quantities of cereal grains, fruits and vegetables are likely to provide sufficient fiber. Due to the fact that gluten-free products generally are not enriched/fortified, and are frequently made from refined flour or starch, they may not contain the same levels of nutrients as the gluten containing counterparts they are intended to replace. Therefore, uncertainty still exists as to whether celiac patients living on a gluten-free diet are ensured a nutriationally balanced diet. Grehn et al. [4] screened the intake of nutrients and foods of 49 adults diagnosed with celiac disease and following a gluten-free diet. They were found to have a lower intake of fiber when compared to a control group of people on a normal diet. Similarly, Lohiniemi et al. [5] found that the average fiber consumption amongst celiac in Sweden was lower than recommended. Moreover, the relationship between food and health has an increasing impact on food innovation due to the popularity of the concept of functional food. The practice of using nutrition knowledge at food product level to improve the health of the consumer forms the general concept of functional foods. In recent years, dietary fiber has received increasing attention from researchers and industry due to the likely beneficial effects on the reduction of coronary heart-related diseases, diabetes incidence and gut neoplasia [6].

The enrichment of gluten-free products with dietary fibers has, therefore, been a topic of research for various teams of technologists [7]. One of these ingredients used by the food industry is inulin, a non-digestible fructooligosaccharide [8] that is classed as a dietary fiber. It also acts as a prebiotic by stimulating the growth of 'healthy' bacteria in the colon [9]. Chemically, inulintype fructans are a linear polydisperse carbohydrate material consisting mainly of D-fructose joined by $\beta$-(2/1) linkages [10]. The last fructose may be linked with a glucose by an $\alpha-(1 / 2)$ bond as in sucrose. Native inulin 
was found to be a semi-crystalline material, which was present in the glassy state at $25^{\circ} \mathrm{C}$ and water activity lower than 0.75 [11]. It is feasible to incorporate dietary fiber ingredients into pasta that may increase its nutriational value to the consumer compared to conventional pasta. Adding inulin to pasta may be a suitable strategy, since it would represent a minimal change in the diet of population and it could be maintained for a long period. In this context, pasta has already been administered as vehicle for testing other substances, such as soy proteins [12].

Among gluten-free flours, maize flour, derived from grounded and desiccated seed of the maize plant (also commonly called corn in many English countries) Zea mays, is the second most produced and consumed flour after wheat flour, competing with rice flour. Maize contains 7 - $13 \mathrm{~g} / 100 \mathrm{~g}$ proteins, is uniquely rich in dietary fibre, vitamin B6, magnesium and it has very low fat content [13]. On the other hand, in order to obtain good quality pasta from alternative materials it is often necessary to modify the traditional production process [14]. In fact, when maize is the only material used in pasta production, it requires some starch gelatinization to act as a binder, since maize protein lacks the functionality of wheat gluten in making a cohesive dough structure. Pre-gelatinization can help to improve functional properties and give body and texture to the product. In the literature, it has also been reported that substances that swell in water could replace gluten in the dough [15]. Therefore, balanced formulations and adequate technological production processes have to be adopted to counteract any changes in the rheological properties caused by the incorporation of these new ingredients [16]. Therefore, the amount of non-conventional flours (quinoa, amaranth, oat, soybean, maize, etc.) that can be added to or substituted for semolina represents a compromise between nutritional improvement of the pasta and achievement of satisfactory sensory properties [16].

The present work is focused on the manufacturing of spaghetti based on maize flour added with inulin up to an amount of $20 \%$. The influence of the content of soluble fiber on both the rheological properties of the dough and the sensory characteristics of dry spaghetti were evaluated. Moreover, the pre-gelatinization process was made by means of injection of saturated steam to improve the spaghetti texture.

Results of this study could provide the industry useful information about potential utilizing of different ingredient, i.e. maize flour and inulin, in food formulations and product development for new functional foods.

\section{Materials and Methods}

\subsection{Spaghetti Preparation}

Maize flour was bought from Bongiovanni mill (Mon- dovì, Cuneo, Italy). To prepare the dough samples, maize flour, inulin (Beneo Orafit, Belgium) and water were mixed, then monoglyceride (Natural World s.r.l., Ravenna, Italy) was added in an amount equal to $0.5 \%$. A steam cooker (LT50 2E Namad, Rome, Italy) was used to prepare the dough with the following process conditions: kneading with $30 \%$ of water for 20 min, injection of saturated steam at temperature of $110^{\circ} \mathrm{C}$ and at pressure of 4.5 bar for $10 \mathrm{~min}$, cooling of the dough to about $40^{\circ} \mathrm{C}$, further addition of water, injection of saturated steam for $12 \mathrm{~min}$ and then cooling of the dough to about $40^{\circ} \mathrm{C}$. The dough based on maize flour (100\%) was manufactured and then used as a reference sample (CTRL).

The percentage weight fraction of raw materials used to prepare the spaghetti samples is reported in Table $\mathbf{1 .}$ Dry spaghetti samples were produced from a pilot plant made of an extruder (60 VR, Namad, Rome, Italy) and a dryer (SG600, Namad). The process conditions applied were listed in Table 2.

\subsection{Dough Rheological Properties}

Elongation and shear viscosity of each dough sample were investigated by means of a Rosand capillary rheometer (Malvern Instruments, Malvern, Worcester, UK) with twin cylinders. Two different length dies with the same diameter $(1 \mathrm{~mm})$ were selected to measure the entry pressure losses. The length of left die was of $10 \mathrm{~mm}$ and the pressure was of 10 psi. Whereas, the length of right die was of $0.25 \mathrm{~mm}$ and the pressure was of $150 \mathrm{psi}$. The experiments were carried out at a temperature of $30^{\circ} \mathrm{C}$ and at shear rate between $10-2000 \mathrm{~s}^{-1}$. The rheological behaviour is studied using the following power law model that satisfactory fitted the experimental data:

$$
\tau_{s}=K \cdot\left(\frac{\mathrm{d} \gamma_{s}}{\mathrm{~d} t}\right)^{n}
$$

and

$$
\tau_{e}=L \cdot\left(\frac{\mathrm{d} \gamma_{e}}{\mathrm{~d} t}\right)^{m}
$$

Table 1. Formulations used in the preparation of spaghetti samples.

\begin{tabular}{ccc}
\hline Samples & Mais (\%) & Inulin (\%) \\
\hline 1 & 95 & 5 \\
2 & 92.5 & 7.5 \\
3 & 90 & 10 \\
4 & 87.5 & 12.5 \\
5 & 85 & 15 \\
6 & 80 & 20 \\
CTRL & 100 & - \\
\hline
\end{tabular}


Table 2. Process conditions used to manufacture the dry spaghetti.

\begin{tabular}{|c|c|c|c|c|c|c|c|c|}
\hline Samples & $\begin{array}{l}\text { Water }^{\mathrm{a}} \\
(\%)\end{array}$ & $\begin{array}{l}\text { Iniection vapor } \\
\text { time (min) }\end{array}$ & $\begin{array}{l}\text { Drying temperature } \\
\text { I step }\left({ }^{\circ} \mathrm{C}\right)\end{array}$ & $\begin{array}{l}\text { Drying time } \\
\text { I step (min) }\end{array}$ & $\begin{array}{l}\text { Drying temperature } \\
\text { II step }\left({ }^{\circ} \mathrm{C}\right)\end{array}$ & $\begin{array}{l}\text { Drying time } \\
\text { II step (min) }\end{array}$ & $\begin{array}{l}\text { Drying temperature } \\
\text { III step }\left({ }^{\circ} \mathrm{C}\right)\end{array}$ & $\begin{array}{l}\text { Drying time } \\
\text { III step (min) }\end{array}$ \\
\hline 1 & 38 & 16 & 50 & 60 & 80 & 300 & 70 & 40 \\
\hline 2 & 37 & 16 & 50 & 60 & 80 & 300 & 70 & 40 \\
\hline 3 & 36 & 16 & 50 & 60 & 80 & 300 & 70 & 40 \\
\hline 4 & 40 & 16 & 50 & 60 & 80 & 300 & 70 & 40 \\
\hline 5 & 34 & 16 & 50 & 60 & 80 & 300 & 70 & 40 \\
\hline 6 & 34 & 16 & 50 & 60 & 80 & 300 & 70 & 40 \\
\hline CTRL & 40 & 16 & 50 & 60 & 80 & 300 & 70 & 40 \\
\hline
\end{tabular}

a $\%$ w/w flour basis.

Where $\tau_{s}$ and $\tau_{e}$ are the shear stress [Pa] and extensional stress $[\mathrm{kPa}], \mathrm{K}$ and $\mathrm{L}$ are the consistency indices $\left[\mathrm{Pa} \cdot \mathrm{s}^{\mathrm{n}}\right.$ and $\mathrm{kPa} \cdot \mathrm{s}^{\mathrm{n}}$, respectively], the $\frac{\mathrm{d} \gamma_{s}}{\mathrm{~d} t}$ and $\frac{\mathrm{d} \gamma_{e}}{\mathrm{~d} t}$ are the shear and extension rate $[1 / \mathrm{s}]$, and $\mathrm{n}$ and $\mathrm{m}$ are the flow indices (dimensionless). The elongation and shear viscosity ( $\eta_{e}$ and $\eta_{s}$, respectively) were calculated on the range of shear and extension rate tested by using the following power law model $[17,18]$ :

$$
\eta_{s}=K \cdot\left(\frac{\mathrm{d} \gamma_{s}}{\mathrm{~d} t}\right)^{n-1}
$$

and

$$
\eta_{e}=L \cdot\left(\frac{\mathrm{d} \gamma_{e}}{\mathrm{~d} t}\right)^{m-1}
$$

The Bagley correction was applied to all data from Rosand rheometer. Three measurements of the viscosity experiment were performed on each sample.

\subsection{Sensory Analysis}

Dry spaghetti samples were submitted to a panel of ten trained tasters in order to evaluate the sensorial attributes. The panelists were selected on the basis of their sensory skills (ability to accurately determine and communicate the sensory attributes, appearance, odor, flavor and texture of a product) [19]. The panelists were however trained in sensory vocabulary and identification of particular attributes, prior to testing, by evaluating comercial conventional and non-conventional pasta.

The panelists were asked to indicate color, homogeneity, resistance to break and overall acceptability of noncooked spaghetti. Elasticity, firmness, bulkiness, adhesiveness, color, odor, taste and overall quality of cooked spaghetti were also evaluated.

To this aim, a nine-point hedonic rating scale, where 1 corresponded to extremely unpleasant, 9 to extremely pleasant and 5 to satisfactory was used to quantify each attribute [20,21].

\subsection{Statistical Analysis}

The rheological and sensorial properties of inulin-enriched gluten free pasta as affected by different amounts of inulin were evaluated in this study. The lowest and highest content of inulin was chosen from results of preliminary laboratory tests. The results of the rheological and sensorial analysis were compared by a one-way variance analysis (ANOVA). A Duncan's multiple range test, with the option of homogeneous groups ( $p<0.05)$, was carried out to determine significant differences between spaghetti samples. STATISTICA 7.1 for Windows (StatSoft, Inc, Tulsa, OK, USA) was used for this aim.

\section{Results and Discussion}

\subsection{Rheological Measurement}

Figures 1 and $\mathbf{2}$ show elongation and shear viscosity as a function of extension rate and shear rate, respectively. As can be inferred from these figures, the viscosity increases with shear rate showing a shear-thickening behavior of the dough [22]. From Figures 1 and 2, it can be seen that the 1 and 2 samples with inulin at 5\% and 7.5\%, respecttively, show the highest values of elongation and shear viscosity with respect to the other samples. In fact, the consistency indices L and K for these samples (Table 3), obtained by fitting Equations (1) and (2) to the experimental data, showed the highest values. On the other hand, the CTRL and 4 samples showed the lower value of elongation and shear viscosity, in fact Table 3 highlights that these samples had the lowest value of the consistency indices $\mathrm{L}$ and $\mathrm{K}$. It is worth noting that for samples 5 and 6, which have highest percentage of inulin, it was not possible to perform rheological measurements because of high firmness of these doughs. Therefore, the increase of the inulin amount over $12.5 \%$ led to an in- 


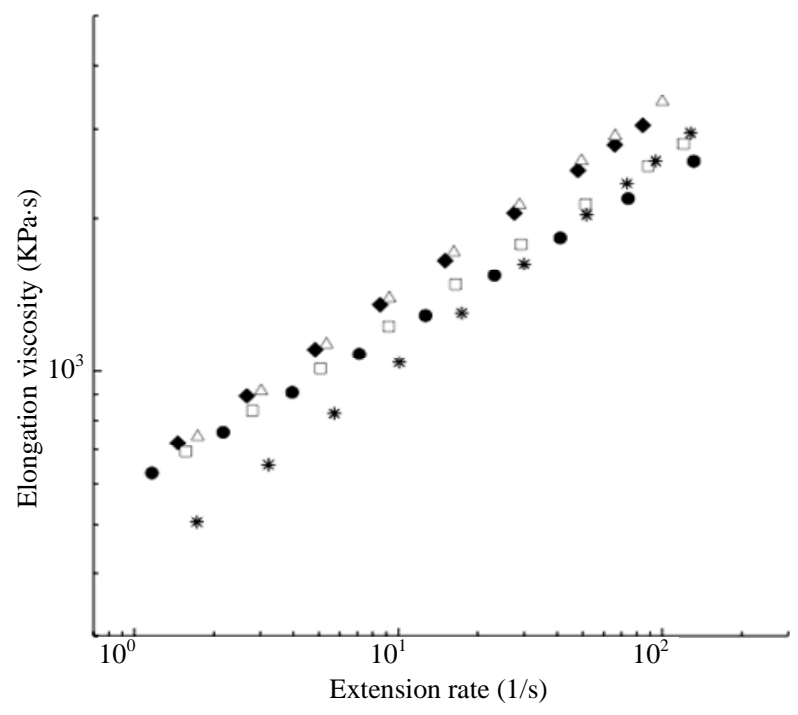

Figure 1. Elongation viscosity as a function of extension rate for all manufactured spaghetti samples. $(\diamond)$ sample $1 ;(\triangle)$ sample 2; (*) sample 3; (•) sample 4; (*) CTRL.

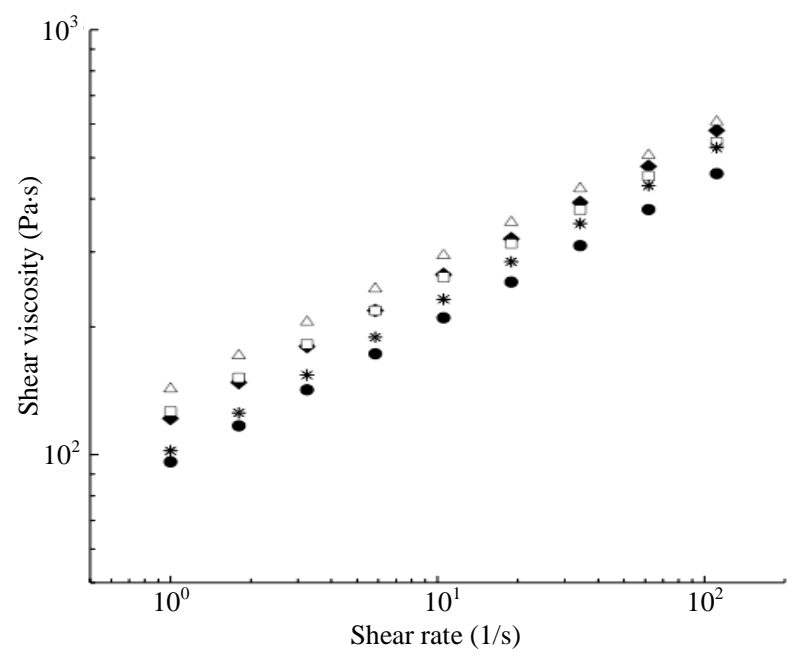

Figure 2. Shear viscosity as a function of shear rate for all manufactured spaghetti samples. $(\diamond)$ sample $1 ;(\triangle)$ sample 2; (*) sample 3; (•) sample 4; (*) CTRL.

Table 3. Values of the consistency indices ( $L$ and $K)$ and the flow indices ( $m$ and $n$ ) obtained by fitting Equqtions (1) and (2) to the experimental data.

\begin{tabular}{cccccc}
\hline Samples & Inulin (\%) & $\mathbf{L}$ & $\mathbf{~ m}$ & $\mathbf{K}$ & $\mathbf{n}$ \\
\hline 1 & $5 \%$ & $631.0721^{\mathrm{a}}$ & $1.3552^{\mathrm{a}}$ & $56.750^{\mathrm{a}}$ & $1.3313^{\mathrm{a}}$ \\
2 & $7.5 \%$ & $604.5814^{\mathrm{b}}$ & $1.3743^{\mathrm{b}}$ & $70.467^{\mathrm{b}}$ & $1.3071^{\mathrm{b}}$ \\
3 & $10 \%$ & $600.1222^{\mathrm{b}}$ & $1.3222^{\mathrm{c}}$ & $61.992^{\mathrm{c}}$ & $1.3095^{\mathrm{b}}$ \\
4 & $12.5 \%$ & $601.2741^{\mathrm{b}}$ & $1.2999^{\mathrm{b}}$ & $44.834^{\mathrm{d}}$ & $1.3316^{\mathrm{a}}$ \\
CTRL & - & $404.6360^{\mathrm{c}}$ & $1.4091^{\mathrm{d}}$ & $45.7749^{\mathrm{d}}$ & $1.3486^{\mathrm{c}}$ \\
\hline
\end{tabular}

${ }^{\mathrm{a}-\mathrm{d}}$ Mean in the same column followed by different superscript letters differs significantly $(\mathrm{p}<0.05)$. crease of the dough firmness.

Peressini and Sensidoni [23] found that the storage modulus of wheat dough increased with increasing levels of inulin polymerization degree. Moreover, the addition of $7.5 \%$ of inulin resulted in storage modulus values that were about 3 and 4 times that of the base flours.

\subsection{Sensory Analysis of Dry Spaghetti Samples}

The sensorial properties of the dry spaghetti samples are listed in Table 4. In particular, the sensorial attributes of cooked and non-cooked spaghetti were determined. Regarding the non-cooked spaghetti, all samples had positive score of overall quality. In particular, sample 1 with $5 \%$ of inulin showed the highest score because of the highest resistance to break value. On the other hand, the increase of the inulin content causes less resistant spaghetti with respect to the CTRL sample. Regarding the cooked spaghetti, all samples had a positive score of overall quality. Moreover, it is possible to observe that the overall quality decreased with the increase of the amount of inulin. This result is due to the fact that the score of attributes such as firmness, color and taste decreased with the increase of the inulin amount influenceing negatively the overall quality of the spaghetti samples. Specially, the firmness of spaghetti containing the highest amount of inulin (20\%) appeared to be generally lower than the CTRL sample, in fact it was scored around the acceptability threshold (i.e., five). Tudorica et al. [24] reported similar results in their paper based on pasta fortified with inulin, pea fiber, and guar gum.

Pasta firmness can be related to the hydration of the starch granules during the cooking process and the subsequent embedding of gelatinizing starch granules in the matrix. As such, the decreased in firmness may be associated with a reduction in starch gelatinization in the pasta [25]. Dietary fibers which is highly water-binding macromolecules is competing with starch for water absorption and hence limiting starch swelling and gelatinization resulting in a higher endothermic peak temperatures value [26]. High transition temperatures have also been reported to result from a high degree of starch crystallinity, which provides structural stability and makes the granule more resistant toward gelatinization [27]. The reduction in starch swelling within the samples containing inulin would result from the inulin preferentially hydrating, aggregating, and forming a matrix, encasing starch granules in a semisolid gel [28]. This encasing of the starch granules would possibly limit water movement to the starch granules in the pasta, reducing gelatinization events.

\section{Conclusions}

The rheological properties of dough based on gluten free 
Table 4. Sensory characteristics of dry cooked and non-cooked spaghetti samples.

\begin{tabular}{|c|c|c|c|c|c|c|c|c|c|c|c|}
\hline \multirow[b]{2}{*}{ Samples } & \multicolumn{4}{|c|}{ Non-cooked spaghetti } & \multicolumn{7}{|c|}{ Cooked spaghetti } \\
\hline & Colour & Homogeneity & $\begin{array}{l}\text { Resistance } \\
\text { to break }\end{array}$ & $\begin{array}{l}\text { Overall } \\
\text { quality }\end{array}$ & Elasticity Firmness & Bulkiness & Adhesiveness & Colour & Odor & Taste & $\begin{array}{l}\text { Overall } \\
\text { quality }\end{array}$ \\
\hline $5 \%$ & $8.0^{\mathrm{a}} \pm 0.0$ & $6.1^{\mathrm{a}} \pm 0.2$ & $7.0^{\mathrm{a}, \mathrm{c}} \pm 0.0$ & $7.3^{b, c} \pm 0.3$ & $5.7^{\mathrm{a}} \pm 0.5 \quad 7.0^{\mathrm{c}} \pm 0.0$ & $8.6^{\mathrm{a}} \pm 0.6$ & $7.4^{\mathrm{a}} \pm 0.4$ & $8.0^{\mathrm{c}} \pm 0.0$ & $7.9^{\mathrm{a}} \pm 0.2$ & $7.8^{c} \pm 0.3$ & $7.2^{\mathrm{c}, \mathrm{d}} \pm 0.3$ \\
\hline $7.5 \%$ & $7.8^{\mathrm{a}, \mathrm{b}} \pm 0.3$ & $5.7^{\mathrm{a}} \pm 0.3$ & $6.8^{\mathrm{a}} \pm 0.3$ & $6.8^{\mathrm{a}, \mathrm{b}, \mathrm{c}} \pm 0.3$ & $35.5^{\mathrm{a}} \pm 0.56 .8^{\mathrm{c}, \mathrm{d}} \pm 0.3$ & $38.2^{\mathrm{a}} \pm 0.5$ & $7.6^{\mathrm{a}} \pm 0.4$ & $7.7^{\mathrm{c}} \pm 0.3$ & $7.7^{\mathrm{a}, \mathrm{c}} \pm 0.3$ & $7.3^{b} \pm 0.3$ & $7.0^{\mathrm{b}, \mathrm{c}, \mathrm{d}} \pm 0.0$ \\
\hline $10 \%$ & $8.0^{\mathrm{a}} \pm 0.0$ & $6.2^{\mathrm{a}} \pm 0.3$ & $6.7^{\mathrm{a}} \pm 0.3$ & $6.8^{\mathrm{a}, \mathrm{b}, \mathrm{c}} \pm 0.3$ & $35.4^{\mathrm{a}} \pm 0.56 .3^{\mathrm{b}, \mathrm{d}} \pm 0.5$ & $58.4^{\mathrm{a}} \pm 0.6$ & $7.5^{\mathrm{a}} \pm 0.5$ & $6.8^{\mathrm{b}} \pm 0.3$ & $7.3^{\mathrm{b}, \mathrm{c}} \pm 0.3$ & $3.2^{\mathrm{a}, \mathrm{b}} \pm 0.3$ & $6.6^{\mathrm{a}, \mathrm{b}, \mathrm{c}} \pm 0.4$ \\
\hline $12.5 \%$ & $7.6^{\mathrm{b}} \pm 0.4$ & $5.8^{\mathrm{a}} \pm 0.3$ & $6.7^{\mathrm{a}} \pm 0.3$ & $6.7^{\mathrm{a}, \mathrm{b}} \pm 0.3$ & $5.4^{\mathrm{a}} \pm 0.56 .0^{\mathrm{a}, \mathrm{b}} \pm 0.0$ & $8.6^{a} \pm 0.6$ & $7.6^{\mathrm{a}} \pm 0.4$ & $6.5^{\mathrm{a}, \mathrm{b}} \pm 0.4$ & $47.2^{b} \pm 0.3$ & $7.0^{\mathrm{a}, \mathrm{b}} \pm 0.0$ & $6.5^{\mathrm{a}, \mathrm{b}, \mathrm{c}} \pm 0.5$ \\
\hline $15 \%$ & $7.9^{\mathrm{a}, \mathrm{b}} \pm 0.2$ & $5.7^{\mathrm{a}} \pm 0.5$ & $6.5^{\mathrm{a}, \mathrm{b}} \pm 0.5$ & $6.5^{\mathrm{a}} \pm 0.4$ & $5.3^{\mathrm{a}} \pm 0.55 .9^{\mathrm{a}, \mathrm{b}} \pm 0.2$ & $28.4^{\mathrm{a}} \pm 0.6$ & $7.7^{\mathrm{a}} \pm 0.3$ & $6.5^{\mathrm{a}, \mathrm{b}} \pm 0.5$ & $7.2^{b} \pm 0.3$ & $6.8^{\mathrm{a}} \pm 0.3$ & $6.3^{\mathrm{a}, \mathrm{b}} \pm 0.5$ \\
\hline $20 \%$ & $8.0^{\mathrm{a}} \pm 0.0$ & $5.7^{\mathrm{a}} \pm 0.5$ & $6.0^{\mathrm{b}} \pm 0.5$ & $6.2^{\mathrm{a}} \pm 0.3$ & $5.3^{\mathrm{a}} \pm 0.5 \quad 5.5^{\mathrm{a}} \pm 0.4$ & $9.0^{\mathrm{a}} \pm 0.0$ & $7.9^{\mathrm{a}} \pm 0.2$ & $6.1^{\mathrm{a}} \pm 0.0$ & $7.9^{\mathrm{a}} \pm 0.2$ & $6.8^{\mathrm{a}} \pm 0.3$ & $6.0^{\mathrm{a}} \pm 0.5$ \\
\hline CTRL & $8.0^{\mathrm{a}} \pm 0.0$ & $6.3^{\mathrm{a}} \pm 0.5$ & $7.5^{\mathrm{c}} \pm 0.4$ & $7.4^{\mathrm{c}} \pm 0.4$ & $5.7^{\mathrm{a}} \pm 0.5 \quad 7.4^{\mathrm{c}} \pm 0.6$ & $8.6^{a} \pm 0.6$ & $7.5^{\mathrm{a}} \pm 0.4$ & $8.0^{c} \pm 0.0$ & $8.0^{\mathrm{a}} \pm 0.0$ & $8.0^{c} \pm 0.0$ & $7.6^{\mathrm{d}} \pm 0.4$ \\
\hline
\end{tabular}

${ }^{\mathrm{a}-\mathrm{d}}$ Mean in the same column followed by different superscript letters differs significantly $(\mathrm{p}<0.05)$.

flour enriched with inulin and the sensorial attributes of the manufactured spaghetti samples were evaluated in this work. Results highlight that the samples with inulin at $5 \%$ and $7.5 \%$ showed the higher values of elongation and shear viscosity with respect to the other samples, therefore they showed a higher firmness.

Regarding the sensorial analysis, all dry samples had a positive score of overall quality; in particular, the sample with $5 \%$ of inulin showed the highest score because of the highest resistance to break. Moreover, the overall quality of the cooked spaghetti samples decreased with the increase of the amount of inulin. In fact, firmness, colour and taste attributes decreased with the increase of the inulin amount influencing negatively the overall quality of the spaghetti samples that remains above the acceptability threshold (score of 6.0).

In conclusion, the obtained results show that the pasta tested in this study could be a suitable alternative to conventional gluten free pasta based on their superior nutriative value.

\section{Acknowledgements}

This research work, which falls into the Strategic Project "Process innovation for production of functional pasta", PS_003 was financially supported by the Apulia Region.

\section{REFERENCES}

[1] P. Feillet and J. E. Dexter, "Quality Requirements of Durum Wheat for Semolina Milling and Pasta Production,” In: J. E. Kruger, R. R. Matsuo and J. W. Dick, Eds., Pasta and Moodle Technology, American Association of Cereal Chemists, St. Paul, 1996, pp. 95-111.

[2] D. D. Kasarda, "Grain in Relation to Celiac Disease,” Cereal Foods World, Vol. 46, 2001, p. 209.

[3] S. R. Kelly, M. Shashidharan, B. Borwell, A. M. Tromans, D. Finnis and D. J. Grundy, "The Role of Intestinal Stoma in Patients with Spinal Cord Injury,” Spinal Cord, Vol.
37, No. 3, 1999, pp. 211-214. doi:10.1038/sj.sc.3100764

[4] S. Grehn, K. Fridell, M. Lilliecreutz and C. Hallert, "Dietary Habits of Swedish Adult Coeliac Patients Treated by a gluten-Free Diet for 10 Years,” Scandanavian Journal of Nutrition, Vol. 45, 2001, pp. 178-182.

[5] S. Lohiniemi, M. Maki, K. Kaukinen, P. Laippala and P. Collin, "Gastrointestinal Symptoms Rating Scale in Coeliac Patients on Wheat Starch-Based Gluten-Free Diets," Scandanavian Journal of Gastroenterology, Vol. 35, No. 9, 2000, pp. 947-949. doi:10.1080/003655200750023002

[6] F. Brighenti, “Carboidrati e fibra,” In: A. M. Costantini, C. Cannella and G. Tomassi, Eds., II Pensiero Scientifico Editore, Rome, 1999, pp. 197-222.

[7] Codex Alimentarius Commission, "Draft Revised Standard for Gluten Free Foods (CX/NFSDU 98/4),” In: Codex Committee on Nutrition and Foods for Special Dietary Uses, 22nd Session, Berlin, 2000.

[8] B. Tungland, “A Call for Dietary Fibre Status for Inulin,” Cereal Foods World, Vol. 45, No. 9, 2000, pp. 413-413.

[9] G. R. Gibson and M. B. Roberfroid, "Dietary Modulation of the Human Colonic Microbiota: Introducing the Concept of Prebiotics," Journal of Nutrition, Vol. 125, No. 6, 1995, pp. 1401-1412.

[10] M. B. Roberfroid, “Introducing Inulin-Type Fructans,” British Journal of Nutrition, Vol. 93, Suppl. 1, 2005, pp. S13S25. doi:10.1079/BJN20041350

[11] J. E. Zimeri and J. L. Kokini, "Rheological Properties of Inulin-Waxy Maize Starch Systems,” Carbohydrate Polymers, Vol. 52, No. 1, 2003, pp. 67-85. doi:10.1016/S0144-8617(02)00268-0

[12] C. Clerici, K. D. Setchell, P. M. Battezzati, M. Pirro, V. Giuliano, S. Asciutti, D. Castellani, E. Nardi, G. Sabatino, S. Orlandi, M. Baldoni, O. Morelli, E. Mannarino and A. Morelli, "Pasta Naturally Eriche with Isoflavone Aglycons from Soy Germ Reduces Serum Lipids and Improves Markers of Cardiovascular Risk," Journal of Nutrition, Vol. 137, No. 10, 2007, pp. 2270-2278.

[13] O. Paredes-Lòpez, S. O. Serna-Saldìvar and S. H. Guzmàn-Maldonado, "Los Alimentos Màgicos de las Culturas Indìgenas de México-El Caso de la Tortilla,” El Colegio 
de Sinaloa, Culiacàn, 2000.

[14] N. L. Kent and A. D. Evers, “Technology of Cereals,” 4th Edition, Elsevier Science, Oxford, 1994.

[15] H. P. Sivaramakrishnan, B. Senge and P. K. Chattopadhyay, "Rheological Properties of Rice Dough for Making Rice Bread,” Journal of Food Engineering, Vol. 62, No. 1, 2004, pp. 37-45. doi:10.1016/S0260-8774(03)00169-9

[16] E. Marconi and M. Carcea, "Pasta from Non Traditional Raw Materials,” Cereal Food World, Vol. 46, No. 11, 2001, pp. 522-530.

[17] M. A. Bertuzzi, M. Armada and J. C. Gottifredi, "Physicochemical Characterization of Starch Based Films,” Journal of Food Engineering, Vol. 82, No. 1, 2007, pp. 17-25. doi:10.1016/j.jfoodeng.2006.12.016

[18] S. A. McGlashan and M. E. Mackay, "Comparison of Entry Flow Techniques for Measuring Elongation Flow Properties," Journal of Non-Newtonian Fluid Mechanics, Vol. 85, No. 2-3, 1999, pp. 213-227. doi:10.1016/S0377-0257(98)00189-X

[19] M. Meilgaard, G. V. Civille and B. T. Carr, "Sensory Evaluation Techniques,” 3rd Edition, CRC Press, Boca Raton, 1999. doi:10.1201/9781439832271

[20] M. Petitot, L. Boyer, C. Minier and V. Valérie Micard, "Fortification of Pasta with Split Pea and Faba Bean Flours: Pasta Processing and Quality Evaluation,” Food Research International, Vol. 43, No. 2, 2010, pp. 634-641. doi:10.1016/j.foodres.2009.07.020

[21] S. Chillo, J. Laverse, P. M. Falcone and M. A. Del Nobile, "Effect of Carboxymethylcellulose and Pregelatinized Corn Starch on the Quality of Amaranthus Spaghetti,” Journal of Food Engineering, Vol. 83, No. 4, 2007, pp. 492-500. doi:10.1016/j.jfoodeng.2007.03.037
[22] C. J. Carriere, “The Effect of Amylose Content from Differing Botanical Sources on the Nonlinear Viscoelastic Properties of Semidilute Solutions of Maize Starches,” Journal of Applied Polymer Science, Vol. 73, No. 12, 1999, pp. 2429-2436. doi:10.1002/(SICI)1097-4628(19990919)73:12<2429::AI D-APP11>3.0.CO;2-B

[23] D. Peressini and A. Sensidoni, "Effect of Soluble Dietary Fibre Addition on Rheological and Bread Making Properties of Wheat Doughs,” Journal of Cereal Science, Vol. 49, No. 2, 2009, pp. 190-201. doi:10.1016/j.jcs.2008.09.007

[24] C. M. Tudorica, V. Kuri and C. S. Brennan, "Nutritional and Physicochemical Characteristics of Dietary Fiber Enriched Pasta," Journal of Agriculture and Food Chemistry, Vol. 50, No. 2, 2002, pp. 347-356. doi:10.1021/jf0106953

[25] C. S. Brennan, V. Kuri and C. M. Tudorica, "Inulin-Enriched Pasta: Effects on Textural Properties and Starch Degradation," Food Chemistry, Vol. 86, No. 2, 2004, pp. 189-193. doi:10.1016/j.foodchem.2003.08.034

[26] C. Collar, E. Santos and C. M. Rosell, "Significance of Dietary Fiber on the Viscometric Pattern of Pasted and Gelled Flour-Fiber Blends," Cereal Chemistry, Vol. 83, No. 4, 2006, pp. 370-376. doi:10.1094/CC-83-0370

[27] N. Singh, J. Singh, K. Kaur, N. S. Sodhi and B. S. Gill, "Morphological, Thermal and Rheological Properties of Starches from Different Botanical Sources," Food Chemistry, Vol. 81, No. 2, 2003, pp. 219-231. doi:10.1016/S0308-8146(02)00416-8

[28] V. Tolstoguzov, "Thermodynamic considerations of Starch Functionality in Foods," Carbohydrate Polymers, Vol. 51, No. 2, 2003, pp. 99-111. doi:10.1016/S0308-8146(02)00416-8 